\title{
The use of 2-dimensional mapping in medical research
}

\section{2 次元マップ糖鎖分析法の医療研究への応用}

\author{
Nakagawa, Hiroaki \\ Hitachi High-Technologies Corporation \\ 11-1, Ishikawa-cho, Hitachinaka-shi, Ibaraki-ken, 312-0057
}

(Received on January 16, 2009, accepted on February 3, 2009)

Key Words: HPLC, $N$-glycan, isomer analysis, biosynthesis pathway, medical research

\begin{abstract}
Herein the importance of the 2-dimensional mapping (2-DM) method in medical research area is introduced. This is the most powerful method for the analysis of glycan isomers. Glycans are synthesized by specific enzymes, and the analysis of isomers can lead to the identification of further directly related enzymes. Therefore, structural analysis using 2-DM connects readily to gene or protein expression analysis. Further, glycan purification during 2-DM analysis is also useful for sample preparation for mass spectroscopic analyses. This review describes the application of 2-DM to three research areas, namely, the $\alpha$-mannosidase II alternative pathway, drug resistance in cancer cells, and the diagnosis of bladder cancer.
\end{abstract}

\section{A. Introduction}

Glycans play a number of important roles in cellcell and protein-cell interactions in living organisms. However, glycans may undergo a range of disease-related changes that lead to an imbalance in cell-cell interactions. In 1985, for example, Parekh et al. reported changes in the structure of serum IgG $N$-glycans in cases of rheumatoid arthritis (1). Thus, glycoanalysis is needed in order to diagnose and clarify the mechanism of such diseases. A number of studies on the relationship between glycans and diseases have been reported, and it has been demonstrated that some tumor-markers recognize glycans. The use of mass spectrometry (MS) to analyze glycans has increased with the further development of MS. However, the 2dimensional mapping (2-DM) method using high-performance liquid chromatography (HPLC) remains a useful tool for the study of glycans, and in particular their isomers.

\section{B. Studies on the $N$-glycan biosynthesis pathway}

The $N$-glycan structure on a protein is synthesized by a sequential reaction mediated by a set of enzymes (Fig.

\section{要 約}

医療分野での研究に抢ける 2 次元マップ糖鎖分析法の利 用を紹介する。この分析法は異性体構造の解析に非常に有効 である。糖鎖構造は基質特異性が高い酵素群により合成され る。異性体も含む構造解析により，関連する糖鎖合成酵素を 推定でき, その酵素の発現解析など研究を先に進めることが 容易にできる。また本法による糖鎖精製は質量分析の試料調 製にも有用である。ここでは 2 次元マップ糖鎖分析法を用い た 3 つの研究, $\alpha$-マンノシダーゼ II の迁回経路, 腫瘍の薬剤 耐性, 腫瘍タイプによる発現の違い, を紹介する。

\section{A. はじめに}

糖鎖は生体内で細胞間, 細胞-タンパク質間の情報伝達に 重要な働きをしている。疾患が細胞間の協調作業が崩れた状 態と考えると糖鎖もまた変化をしている可能性がある。1985 年 Parekh らがリウマチで IgG の $N$-結合型糖鎖構造が变化す ることを報告した $(1)$ 。それ以来多くの疾患と糖鎖変化に関す る報告がなされてきたし, また腫瘍マーカーの中にも糖鎖が 対象となっているものも多い。この様に糖鎖解析は診断や疾 患のメカニズムを研究するのに有用である。近年, 質量分析 （MS）の発展により, 糖鎖変化もMS で分析されることが多 くなった。しかし，MS 分析では糖鎖の異性体解析が難しい部 分もあり，2 次元マップ糖鎖分析法は依然として重要な分析法 である。

\section{B. 糖鎖合成経路の解明}

$N$-結合型糖タンパク質糖鎖は, 一連の酵素反応により生 合成される（図 1）（2）。特にN-アセチルグルコサミン 


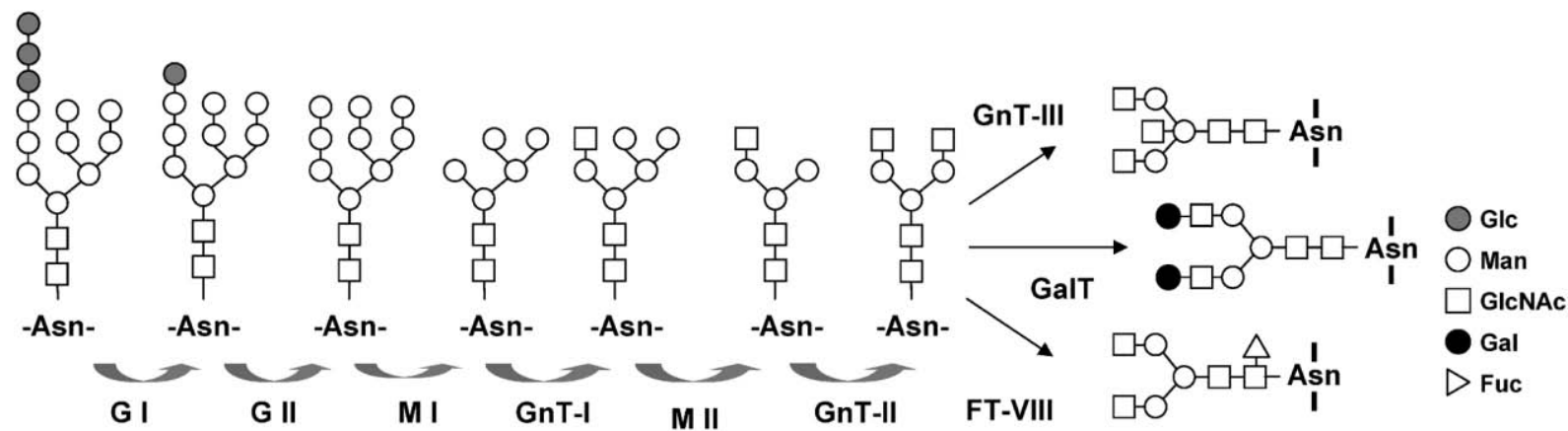

Fig. 1. Biosynthetic pathway of $N$-glycans. $N$-Glycans are formed by the sequential reactions of a set of enzymes. Linkages and substrate specificities are tightly restricted. Variations in $\mathrm{N}$-glycans occur after the GnT-II-mediated reaction. G, glucosidase; M, mannosidase; GnT, $N$-acetylglucosaminyltransferase; GalT, galactosyltransferase; FT, fucosyltransferase.

1) (2). The pathway up to the branching reaction mediated by $N$-acetylglucoaminyltransferase II (GnT-II) is tightly restricted. The enzyme responsible for the change from hybrid type to complex type is $\alpha$-mannosidase II (MII). However, an alternative pathway not involving MII has been suggested since MII-null mice are known to have complex-type oligosaccharides (3). One of the candidate enzymes for the alternative pathway is $\alpha$-mannosidase IIX (MX). MX-null mice have almost the same $N$-glycan pattern as that in wild-type mice, apart from the 310.11 oligosaccharide in the testes, which is needed for the interaction between Sertoli cells and spermatogonia (4). The 310.11 oligosaccharide has two major isomers, 310.1 and 211.1, which vary in glycan structure, and several minor isomers that include the GalNAc-GlcNAc unit (Fig. 2a). Two-DM can distinguish these isomers from 310.11 on the basis of the elution position on an ODS column, and the oligosaccharide can be purified during 2-DM analysis. Using this purified oligosaccharide, cell-cell interactions were confirmed by an inhibition test and the importance of the $\mathrm{N}$-glycan verified. Finally, MX has been confirmed as the enzyme involved in the alternative pathway by the study of MII/MX double-null mice (5). Complex-type $N$-glycans cannot be confirmed by 2-DM; therefore, other peaks that were not in the 2-DM database, were purified and confirmed not to be of the complex type owing to their sensitivity to $\alpha$-mannosidase. The structures of these unknown oligosaccharides were subsequently confirmed by fragmentation analysis using MS (6). Two-DM was, nevertheless, essential to the MS analysis in terms of sample preparation and the supply of standard oligosaccharides for MS/MS fragmentation data MII/MX doublenull mice synthesize unusual $N$-glycans (Fig. 2b). This strongly indicates the importance of $N$-glycans, since mice
（GlcNAc）の分岐が生じるN-アセチルグルコサミン転移醖素 II（GnT-II）反応までは酵素の基質特異性が非常に精密に制 御されている。その一連の酵素反応の中でハイブリッド型糖 鎖からコンプレックス型糖鎖へ転換する酵素が， $\alpha$-マンノシ ダーゼII（MII）である。そのノックアウトマウスがコンプレ ックス型糖鎖を持っていることから，代替経路があることが 知られていた $(3)$ 。その代替経路の酵素候補の一つが， $\alpha$-マン ノシダーゼ IIX（MX) である。MXのノックアウトマウスが 作成されたが，糖鎖は殆ど変化していなかった。詳細な検討 の結果, 精巣糖鎖の中で 310.11 と呼ばれる量比が変化し，そ の糖鎖がセルトリ細胞と精源細胞の相互作用に必要なことが 解かった (4)。310.11 糖鎖にも異性体構造が知られているが, まれに出てくる GalNAc-GlcNAc 構造を除くと, 主には 310.1, 211.1 という 2 種類になる（図 2)。これらの糖鎖とは 2 次元 マップ法では, ODS カラムからの溶出位置が異なるので区別 でき，同時に精製もできる。糖鎖精製ができたことにより， この糖鎖を細胞接着阻害試験に供することができ，細胞間接 着に重要であることが証明できた。最終的に，MII/MX ダブ ルノックアウトマウスを作成したときに，まず精製された糖 鎖ピークのうち 2 次元マップで同定された糖鎖にコンプレッ クス型が無かったこと, 未同定糖鎖ピークもマンノシダーゼ 消化により移動した事により確認され，MXがこの反応を担 っていることが証明された (5)。更に 2 次元マップにて未同定 の糖鎖構造も, MS のフラグメンテーション解析で構造が明ら かになった (6)。MSによるフラグメンテーション解析は糖鎖 の異性体も区別できるが，MS 分析にかける前の精製や，バッ クデータをとるための標準糖鎖の作成に 2 次元マップ糖鎖解 析法は有用であった。 
a

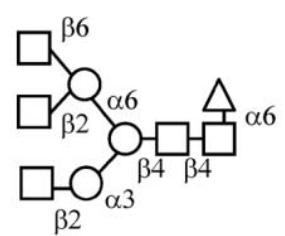

310.11

$(10.4,6.4)$

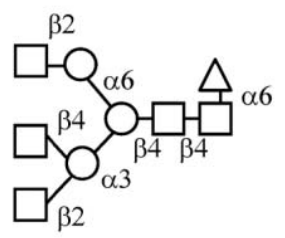

310.1

$(14.8,5.8)$

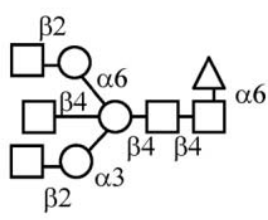

211.1

b
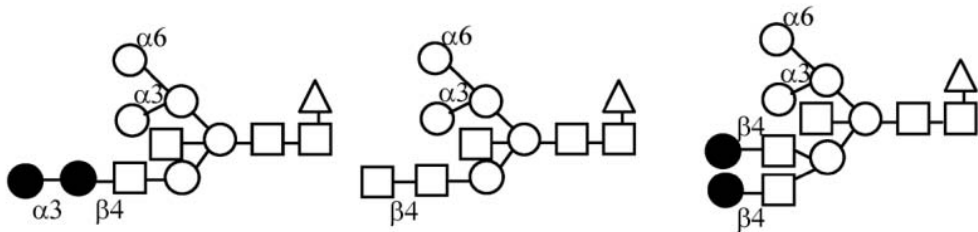

Fig. 2. Structures of oligosaccharides. a. 310.11 and its isomers. 310.11 has two major isomers, 310.1 and 211.1. The numbers in parentheses under the figures represent the elution position of 2-DM (in GUs) on an ODS and Amide column, respectively. Symbols for monosugars are as shown in Fig. 1. b. Example of the unique $N$-glycans from MII/MX double-null mice. These oligosaccharides were observed in double-null mice, but in neither MX-null nor wild-type mice.

in which the $N$-glycan biosynthesis pathway is perturbed by genetic modification have been demonstrated to survive through the use of substitute $N$-glycans. MII-null mice can survive even when half of the $N$-glycan structures have been changed. The proportion of complex-type $N$-glycans in wild-type, MII-null, MX-null, and MII/MX doublenull mice is $80 \%, 20 \%, 80 \%$, and $0 \%$, respectively. MII can almost completely substitute for MX activity, and MX can compensate for a quarter of MII activity. Although the expression levels of these enzymes in organs, life stages, and species have been estimated by gene expression studies, the fact that these levels often do not correspond with oligosaccharide structure means that the true proportions and roles of each of these enzymes in cells remain unknown. Contrary to the previous results obtained from mice, we were unable to detect 310.11 in human testis (7) and could not identify any $N$-glycan structure that plays a similar role in humans. This means that male fertility would not be affected by an MX defect in humans. Indeed, the possibility exists that Sertoli cell- spermatogonia interactions in humans are not controlled by an $N$-glycan. Analysis of the combination of glycans and attached proteins is needed to clarify this mechanism. A $50 \%$ reduction
$\mathrm{MII} / \mathrm{MX}$ ダブルノックアウトマウスの糖鎖構造解析の結 果，通常では発現していない糖鎖を合成していることがわか った。このことは生体にとっての糖鎖の必要性を強く示唆す るとともに，遺伝子改変など糖鎖合成系がかく乱された状態 に抏いて，マウスが生き残るために代替糖鎖を模索すること が解かる。 MII ノックアウトマウスは， $N$-結合型糖鎖の半分 以上が元と異なる構造になっても, ほぼ変わりなく活きてい る。複合型糖鎖の凡その割合は, 野生型は $80 \%$, MII $(-/-)$ は $20 \%, \mathrm{MX}(-/-)$ は $80 \%$, ダブルノックアウトマウスは $0 \%$ である。この結果からは MXは MII 活性を $25 \%$ 補完で き, MII は MX をほぼ完全に補完している。MII や MX の遺 伝子発現解析は行われているが，まだまだ生体内での役割分 担にはなぞが多い。更に糖鎖は種差があり，これらの研究は マウスで行われたが，ヒトでは Testisに310.11 は検出できず (7)，ヒトではどの糖鎖がこの役割を果たしているのか不明で ある。即ちヒトでは MX に変異があってもマウスと同じ様な 症状がでるとは限らないし, セルトリ細胞と精原細胞の相互 作用に糖鎖が関与していない可能性もある。これらの解明に は糖鎖のみでなく, ぞの糖鎖がどの様なタンパク質に結合し ているか解析することも重要である。また, MX $(-/-)$ マ 
in 310.11 is sufficient to cause male infertility in mice. This result suggests that even small alterations in glycans can induce critical pathological changes, and emphasizes the fact that glycans must be analyzed quantitatively. These results highlight, in part, the difficulties associated with research on the physiological functions of glycans.

\section{Glycans in drug resistance}

Drug resistance is a major problem associated with the chemotherapeutic treatment of tumors. It not only reduces the therapeutic effect, but also adds significantly to patient suffering. However, the mechanisms of drug resistance are not well understood. Mitoxantrone- and epirubicin-resistant cell lines have been established from a cultured hepatoma cell line and we have compared their glycan profiles (8). It is well known that the branching and fucosylation of $N$-glycans are changed in cancer, and our results also confirmed that the changes in branching associated with different isomers can be induced via GnT mediation. The determination of detailed oligosaccharide structures has been found to suggest related enzymes. While $\mathrm{N}$-acetylglucosaminyltransferase is known to promote branching in $N$-glycans, there are many forms of GnT, each responsible for the synthesis of particular linkages (Fig. 3). Detailed structural analysis using 2-DM is able to point to related enzymes. However, the gene expression of related enzymes is not consistent with their glycan ratio (Fig. 4). This suggests that the formation of the glycans present is the result of total glycan-bound protein synthesis and degradation processes and the supply of nucleotide sugars, and that the amount of glycans present is not dependent solely on the related glycogene. Thus, glycan structures should not be inferred solely on the basis of glycogene expression.

Another study employed a mouse colorectal cancer
ウスは雄性不妊となったが，この原因はこの糖鎖の量が半減 したことである。即ち, 糖鎖の有無という变化で無く, 量的 な変化を分析する必要がある。これらの結果は糖鎖の機能を 研究することの難しさを良く示している。

\section{C. 薬剂耐性培養細胞での糖鎖解析}

癌の薬物療法に扔いて薬剤耐性は大きな問題の一つであ るが，その機構も良く解かっていない。腫瘍の薬剤耐性の獲 得により治療効果が低下するばかりでなく, 投与量の増加に より副作用が強くなる。抗腫瘍薬であるエピルビシンとミト キサントロンに対する薬物耐性株を同じヒト肝癌培養細胞か ら作成し，糖鎖構造を比較した $(8)$ 。腫瘍と糖鎖の分岐構造や フコースの関係は多くの報告があるが, 本件でもコアフコー スや分岐構造に变化が見られた。糖鎖の分岐は GnTにより生 じるが, GnTには幾つものもの種類があり，それぞれ基質特 異性が厳密に決まっている（図3)。分岐の違いにより異性体 構造が生じるが, 2 次元マップによりどの異性体構造変化して いるか解かれば，関連酵素が容易に推定できる。しかし，そ れらの糖鎖合成酵素の遺伝子発現を調べると必ずしも糖鎖構 造比と一致しない（図 4)。細胞の糖鎖構造は直接担当してい る遺伝子のみならず, 結合しているタンパク質の発現・代 謝, 関連する糖又クレオチド供給などにも影響されるためと 考えられる。このことは, 遺伝子発現の変化のみで糖鎖構造 を議論できないことを示唆している。

マウス大腸がん由来腫瘍細胞を用いた別の実験では，同

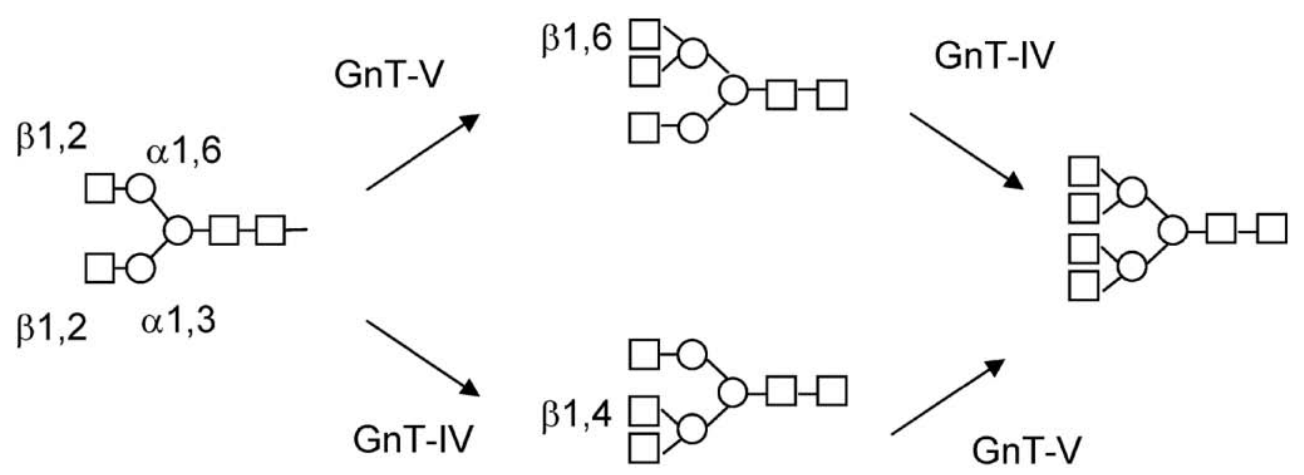

Fig. 3. $N$-Acetylglucosaminyltransferase (GnT) reactions. GnT-V acts to attach GlcNAc to the Man of the $\alpha 1,6$ branch by a $\alpha 1,6$ linkage, and GnT-IV forms the GlcNAc$\beta 1,4-$ Man- $\alpha 1,3$-Man structure. In this way, two major types of triantennary $N$-glycans are formed. The reactions of both enzymes produce tetraantennary oligosaccharides. 


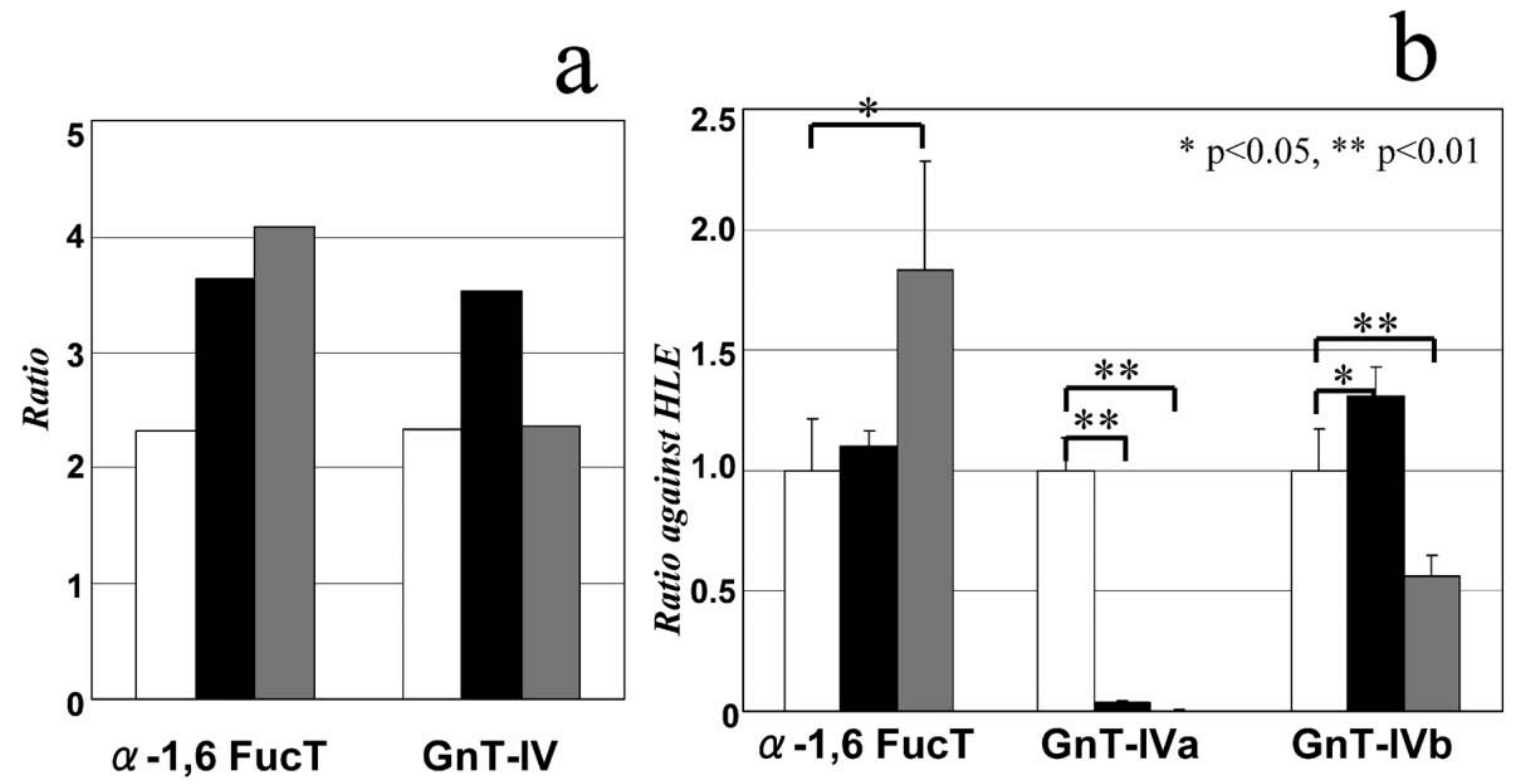

Fig. 4. The ratio of $N$-glycans. The molar ratio was obtained from structural analysis (a) and calculated from the gene expression of relative enzymes (b). The white, black, and gray bars represent parent hepatoma, epirubicin-resistant cells, and mitoxantrone-resistant cells, respectively.

Table 1. Effects of swainsonine treatment on the $\mathbf{I C}_{50}$ values $(\mathrm{mg} / \mathrm{L})$ for 5 -FU against resistant cell lines (9)

\begin{tabular}{lcc}
\hline & Swainsonine $(-)$ & Swainsonine $(+)$ \\
\hline Parent cells & 0.110 & 0.110 \\
Resistant cell line 1 & 1.07 & 0.650 \\
Resistant cell line 2 & 3.87 & 1.45 \\
Resistant cell line 3 & 4.86 & 3.01 \\
\hline
\end{tabular}

cell line, colon 26 (9). Three cell lines with different levels of sensitivity to 5-fluorouracil (5-FU) were established from this parent cell line. Although the $N$-glycan profiles of these three cell lines differed, the alteration responsible for the resistance to 5-FU could not be identified. Gene expression analysis of resistance-related enzymes demonstrated that the mechanism of resistance to 5-FU varies between cell line. Interestingly, swainsonine treatment has a similar effect on their resistance. Treatment with swainsonine did not affect cell growth, but the proportion of complex-type $\mathrm{N}$-glycans was decreased from $80 \%$ to $20 \%$ in the three resistant cell lines. The $\mathrm{IC}_{50}$ value of the parent cells to 5-FU was unchanged, but the $\mathrm{IC}_{50}$ values of the resistant cell lines were decreased by almost half, and the effect of 5-FU was enhanced by swainsonine treatment (Table 1). These results indicate that the mechanism of resistance in each of the three cell lines was different, and that $\mathrm{N}$-glycans play a role in all three mechanisms.
じ親株から 5-フルオロウラシル（5-FU）への耐性強度が異な る3つの耐性株が樹立された。薬剤耐性株の糖鎖パターンは 夫々異なったが，その変化には共通性は無かった。5-FU 耐性 に関連する酵素の発現解析から，これらの細胞株の薬剂耐性 機構が異なることが示されたが，糖鎖合成阻害剂であるスワ ソソニンに対しては同じような反応を示した。このスワンソ ニン処理濃度では細胞の増殖には影響しないが，糖鎖構造解 析より何れの培養細胞株でも $80 \%$ 以上あった複合型糖鎖が 20 $\%$ 程度に減少し, 変わりに混成型や高マンノース型が増加し ていた。これらの糖鎖変化とともに親株では薬剤耐性能（IC50）の值が変化しないが，何れの薬剤耐性株でも約半分とな り 5-FU の効きが良くなった（表 1)。即ち，薬剤耐性機構は 異なるが，何れも糖鎖が関連していることが明らかになっ た。残念ながら糖鎖が薬剂耐性機構にどの様に関与している かまだ明らかではないが，スワンソニンが薬剤耐性を獲得し 
Although the role of the $\mathrm{N}$-glycans is still not clear, swainsonine shows promise as a candidate drug for combination chemotherapy for tumors. Swainsonine has also been examined for its possible application as a chemotherapeutic agent (10). However, its potential use as part of a combination chemotherapy regimen may allow use of a lower dosage than when used alone; thus, it should soon be available for clinical use.

\section{Diagnosis of tumor type}

In contrast to drug resistance, the study of bladder cancer has provided an example of a good correlation between glycogene expression and glycan structures (11). The analysis of glycans from bladder cancer tissue has shown that levels of the 410.16 oligosaccharide, which is synthesized by GnT-V, were increased in patients with superficial cancer compared to those with invasive cancer. Immunostaining of GnT-V on glass slides revealed a correlation between GnT-V expression and survival rate for 33 months in 57 patients and has indicated the possibility of diagnosis using glycans. At present, 2-DM and MS are too time consuming and expensive for diagnostic use, and they are also associated with problems arising from variations in cell composition of the organs sectioned for analysis. Therefore, a combination of analytical methods that includes HPLC, MS, and immunostaining using antibodies or lectins will be necessary for future research and diagnostics.

\section{E. Conclusion}

It can be suggested that there is no limit to the number of possible $N$-glycan-sized oligosaccharide structures since (a) these structures usually comprise 10 to 20 monosaccharides; (b) some of these monosaccharides are known to form isomers, for example, galactose, mannose, and glucose are isomers of hexose; (c) possible linkage sites include the 2, 3, 4, and 6 positions; and (d) linkage can occur in both an $\alpha$ and $\beta$ manner. To date, the identities of only 500 oligosaccharides have been determined and catalogued using 2/3-DM methods, which appears to be a very small number when the unlimited possibilities explained above are taken into consideration. However, as $N$-glycans are synthesized through a well-controlled biosynthetic pathway, this number may, in fact, represent a large proportion of existing oligosaccharides. Further, as information concerning the sample origin and frequency allows us to narrow the focus on possible candidate oligosaccharide structures, and often a specific molecular weight corresponds to only one candidate structure, it is therefore possible to study oligosaccharide structure on the basis of MS data alone.
た腫瘍の治療に使える可能性がある。スワンソニンはそれ自 身で抗腫瘍薬として検討されたこともあるが，今回のものは それよりも少ない細胞毒性が無い投与量であるのでより実用 化が期待できる(10)。

\section{D．糖鎖による腫瘍の識別}

一方糖鎖構造と関連遺伝子が良く協調していた例とし て, 膀胱がんの研究がある(11)。表在性と浸潤性の膀胼がん 組織の糖鎖構造を比較すると, 表在性の腫瘍では 410.16 とい う糖鎖が多かった。この糖鎖合成には GnT-V が関与し，抗 GnT-V 抗体を用いて組織染色を行うことにより，57 例での 33 ヶ月に渡る生存率が検討された。GnT-V 発現群で生存率が 高いことが明確になり，糖鎖による診断の可能性を示した。 現在のところ 2 次元マップ法や MS による糖鎖構造解析は, 直接診断支援に用いるには煩雑でありコストもかかる。また これらの手法では試料となる組織の不均一性の問題もつきま とう。今回のような抗糖転移酵素抗体の他, レクチンや抗糖 鎖抗体などによる組織染色との連携も重要である。

\section{E. 結語}

$N$-結合型糖鎖は通常 10〜20 糖からなる。グルコース・マ ンノース・ガラクトースなど構成糖の異性体，2,3,4,6 位など 結合箇所， $\alpha \cdot \beta$ の結合様式などを考えると 10〜20 糖からな る糖鎖の異性体は無限にありそうに感じる。2/3 次元マップの データベースで 500 種類と言う数は, 上記のような異性体の 可能性を考えれば非常に少ないが，それは生合成が非常に良 くコントロールされているからである。試料の由来や出現頻 度も考えると更に糖鎖構造の候補は絞られ，質量からほぼ 1 つの糖鎖構造を推定できる場合も多く, 従って MS の結果の みで糖鎖構造が議論されることもある。 
It has, however, been shown that cells have the ability to synthesize unusual structures that enable survival under emergency conditions, such as genetic modification in MII/MX double-null mice. Detailed $\mathrm{N}$-glycan analysis in the case of bladder cancer can be readily performed by gene expression analysis or immunostaining examination. In this respect, detailed oligosaccharide analysis remains useful. Nevertheless, the isolation of oligosaccharides is still necessary for the investigation of cell-cell interactions and the preparation of MS standards, and thus 2-DM remains an important tool in medical research, particularly for glycan preparation and the analysis of isomers.

\section{Acknowledgements}

The author would like to thank Dr. M. N. Fukuda, Dr. S.-I. Nishimura, and Dr. C. Ohyama, and their teams, for their helpful advice and assistance. These studies were conducted at the laboratory headed by Dr. S.-I. Nishimura in Hokkaido University, and were supported by a grant for the National Project on "Functional Glycoconjugate Research Aimed at Developing New Industries" from the Ministry of Education, Science, Sports and Culture of Japan; and SENTAN, JST (Japan Science and Technology Agency). The author would also like to thank Dr. Garry Heterick for his assistance in editing the manuscript.
しかし，MII/MX ダブルノックアウトマウスで示したよう に, 遺伝子操作等のように異常な状態では, 細胞は生き残る ために通常には無い糖鎖構造を発現してくる。また，腫瘍組 織の糖鎖研究では, 2 次元マップで異性体が解析できたことに より，それに関連する糖転移酵素の発現解析にすぐ進むこと が出来た。また MS 分析の標準品や, 細胞間の接着試験用試 料などを調製できる。2 次元マップ糖鎖構造解析法は糖鎖精製 や異性体解析技術において糖鎖研究に非常に有用である。

謝辞

本共同研究において大変お世話になりました福田道子先 生, 西村紳一郎先生, 大山力先生及び多くの共同研究者の方 々に深謝いたします。また一連の研究は文部科学省 RR「糖鎖 機能解明とデータベースの構築」, JST 先端計測分析技術・機 器開発事業の一部に依ります。また校正していただいたDr. Garry Heterick に深謝いたします。

\section{References}

1. Parekh, R. B., Dwek, R. A., Sutton, B. J., Fernandes, D. L., Leung, A., Stanworth, D., Rademacher, T. W., Mizuochi, T., Taniguchi, T., Matsuta K., and Kobata, A. (1985) Nature 316, 452-457

2. Kornfeld, R., and Kornfeld, S. (1985) Annu. Rev. Biochem. 54, 631-664

3. Chui, D., Oh-Eda, M., Liao, Y. F., Panneerselvam, K., Lal, A., Marek, K. W., Freez, H. H., Moremen, K. W., Fukuda, N. M., and Marth, J. D. (1997) Cell 90, 157-167

4. Akama, O. T., Nakagawa, H., Sugihara, K., Narisawa, S., Ohyama, C., Nishimura, S., O’Brien, D. A., Moreman, K. W., Millan, J. L., and Fukuda, N. M. (2002) Science 295, 124-127

5. Akama, O. T., Nakagawa, H., Wong, N., Sutton-Smith, M., Dell, A., Morris, H. R., Nakayama, J., Nishimura, S.-I., Kelly, A. P., Moreman, W., Marth, J. D., and Fukuda, N. M. (2006) Proc. Natl. Acad. Sci. USA 103, 8983-8988

6. Hato, M., Nakagawa, H., Kurogochi, M., Akama, O. T., Kelly, A. P., Moreman, W., Marth, J. D., Fukuda, N. M., and Nishimura, S.-I. (2006) Mol. Cell. Proteom. 5, 2146-2157

7. Kyan, A., Kamimura, N., Hagisawa, S., Hatakeyama, S., Koie, T., Yoneyama, T., Arai, Y., Nakagawa, H., Nishimura, S.-I., Miyoshi, E., Hashimoto, Y., and Ohyama, C. (2008) Int. J. Oncol. 32, 129-134

8. Kudo, T., Nakagawa, H., Takahashi, M., Hamaguchi, J., Kamiyama, N., Yokoo, H., Nakanishi, K., Nakagawa, T., Kamiyama, T., Deguchi, K., Nishimura, S.-I., and Todo, S. (2007) Mol. Cancer 6, 32

9. Hamaguchi, J, Nakagawa, H., Takahashi, M., Kudo, T., Kamiyama, N., Sun, B., Oshima, T., Sato, Y., Deguchi, K., Todo, S., and Nishimura, S.-I. (2007) Mol. Cancer 6, 58

10. Goss, P. E., Baptiste, J., Fernandes, B., Baker, M., Dennis, J. W. (1994) Cancer Res. 54, 1450-1457 11. Ishimura, H., Takahashi, T., Nakagawa, H., Nishimura, S.-I., Hagisawa, S., Arai, Y., Horikawa, Y., Habuchi, T., Miyoshi, E., and Ohyama, C. (2006) Clin. Cancer Res. 12, 2506-2511 


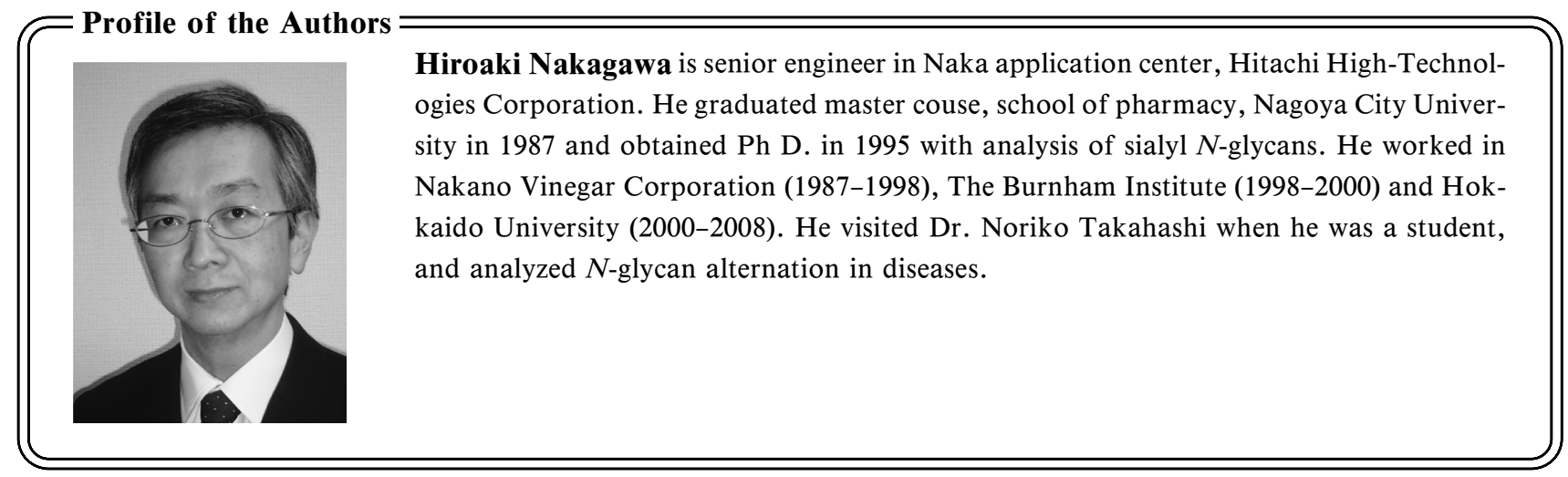

